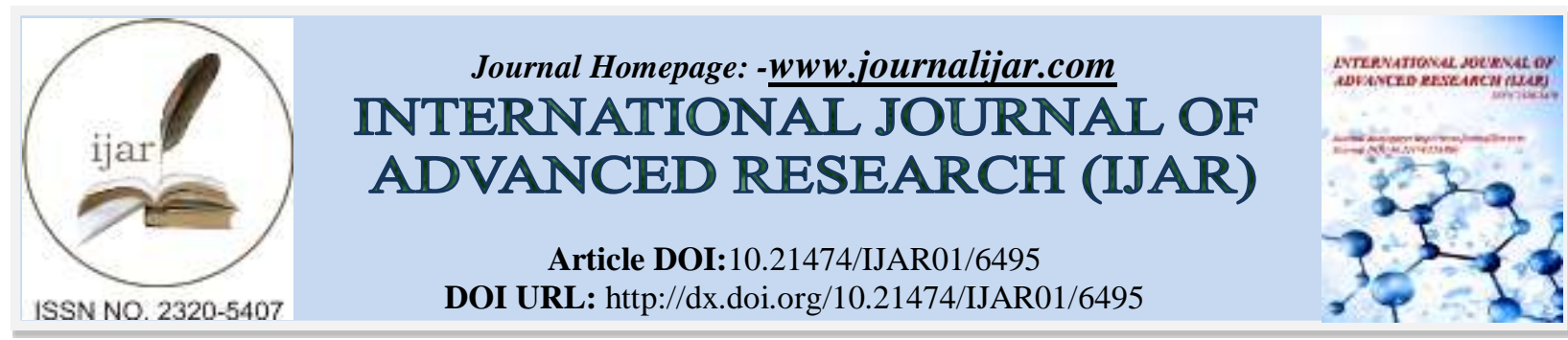

RESEARCH ARTICLE

\title{
QUALITY OF WATER BY PHYSICOCHEMICAL FACTORS AND MACROINVERTEBRATES IN THE AGUAPEY STREAM (PARAGUAY).
}

\section{Alonso. Jorge ${ }^{1}$ and Rodríguez. Estelvina ${ }^{2}$.}

1. Escuela de Posgrado, Universidad Nacional de Itapúa, Encarnación, Paraguay.

2. Facultad de Ciencias y Tecnología, Universidad Nacional de Itapúa, Encarnación, Paraguay.

\section{Manuscript Info}

Manuscript History

Received: 10 December 2017

Final Accepted: 12 January 2018

Published: February 2018

Keywords:-

Water, quality, physicochemical, macroinvertebrates.

\begin{abstract}
This research presents the results of the water quality study of the Aguapey stream (Paraguay) by means of physicochemical parameters and the diversity of aquatic macroinvertebrates. Samples were performed between the season of September 2016 and July 2017, in four locations alongside the water course, three were performed in the main channel and one in the urban tributary of the Cai Puente stream. Simplified Index Water Quality (ISQA) was used. Biodiversity founded on communities was considered through the Dominance, Simpson, Berger-Parker and Shannon-Wiener indexes. It was found that the waters of the Aguapey stream felt into the turbid category (moderately polluted with organic matter), being stations one and two most affected due to agricultural activities, remarkably improving downstream. Conversely, the Cai Puente stream was the most affected (polluted) due to sewages from domestic service and industrial activities, with very excessive levels of total phosphorus and fecal coliforms. Results show that the wealth and species variety were influenced by organic pollution. Diversity of macroinvertebrates could represent adequate assessment instruments for the routine monitoring of the ecological status of the basins and streams of the region.
\end{abstract}

Copy Right, IJAR, 2018,. All rights reserved.

\section{Introduction:-}

Benefits that natural bodies of water (streams, rivers and lakes) provide to the human population, both at a socioeconomic level and in terms of ecosystem services, make them very essential elements when considering environmental management and conservation approaches. (Garcia \& Pargament, 2014; Rodriguez et al., 2016).

Understanding how human actions affect the environments of aquatic ecosystems enables not only to evaluate impacts, nonetheless, it also helps decision-making for sustainable development. Many human activities have adverse effects on ecosystems, some of which are the modifications flow, habitat degradation, exploitation, pollution and the insertion of exotic species that result in significant transformations in water bodies and biodiversity present in the location (Dudgeon, et al., 2006; Ramírez, et al., 2008; Gutiérrez-Fonseca \& Ramírez, 2016). 
The use of the simplified water index (ISQA) to analyze the physicochemical parameters is of great importance, since it allows to find consistent results rapidly and in a low-cost, being a useful instrument to recognize water quality as well as to identify sources of contamination (Bustamante et al.,2002).

Nonetheless, to complement the information of the physical-chemical features it is appropriate to also include the biotic components whose sensitivity to changes in the physical environment allows a more precise environmental assessment. (Rodriguez Badillo, et al., 2016). With biological indicators, the response of living organisms that are exposed to contaminants or that can be helpful for predicting future damage is valued and can even present the dangerous effects by themselves.

Biological indexes have the advantages that their measurement is not restricted to the time of sampling, subsequently they allow discovering changes produced over time, because living organisms have evolutionary adaptations to certain environmental conditions and have limits of tolerance to the diverse alterations (Alvarez, 2007).

Benthic macroinvertebrates are one of the most appropriate groups for the purposes of assessing quality of aquatic ecosystems (Rodriguez Badillo et al., 2016), being one of the most used for their ability to detect the alteration (Prat et al., 2009; Arocena Real de Azúa et al., 2016), their ubiquity as functional nutrition group and the ability of some groups to withstand hypoxic environments. (López-López y Sedeño-Díaz, 2015; Rodriguez Badillo et al., 2016).

The Aguapey stream is situated in the Paraná River basin, South America, being one of the most affected by anthropogenic actions in the last decades. Located in the Department of Itapúa, the Oriental Region of Paraguay (Figure $\mathrm{N}^{\mathrm{o}}$ 1), with a subtropical climate, ideal for agricultural activities; the cultivation of rice with irrigation is one of the most important farming activities in the Aguapey basin, increasing the area from 8750 hectares to 50,950 hectares in the last decade (Friedmann y Weil, 2010; CAN, 2015). The stream course was affected by the reservoir of the Yacyreta Hydroelectric and it was dammed, but it was diverted by a channel of about $12,5 \mathrm{~km}$, to lastly end in the Brazo Aña Cua in the Paraná river. The study derives from the necessity to provide ecological and scientific evidence concerning the water quality of the stream Aguapey using physicochemical factors and multiplicity of aquatic macroinvertebrates.

\section{Material and Methods:-}

The study was performed in three sampling stations of the Aguapey stream (Juguai E1 (-27.098841, -056.275909), Route $\mathrm{N}^{\circ} 1$ E2 (-27.138210, -056.291042) and another in reservoir E3 (-27.28378, -056.27724); and one more in the urban stream Cai Puente (E4) (-27.157839, -056.242239), in Coronel Bogado city, during different time of the year (the first sampling in spring, the second one in summer, the third one in autumn and the fourth sampling was made in Winter) to have a time and location representation of the environmental situation (Figure $\mathrm{N}^{\circ} 1$ ) 


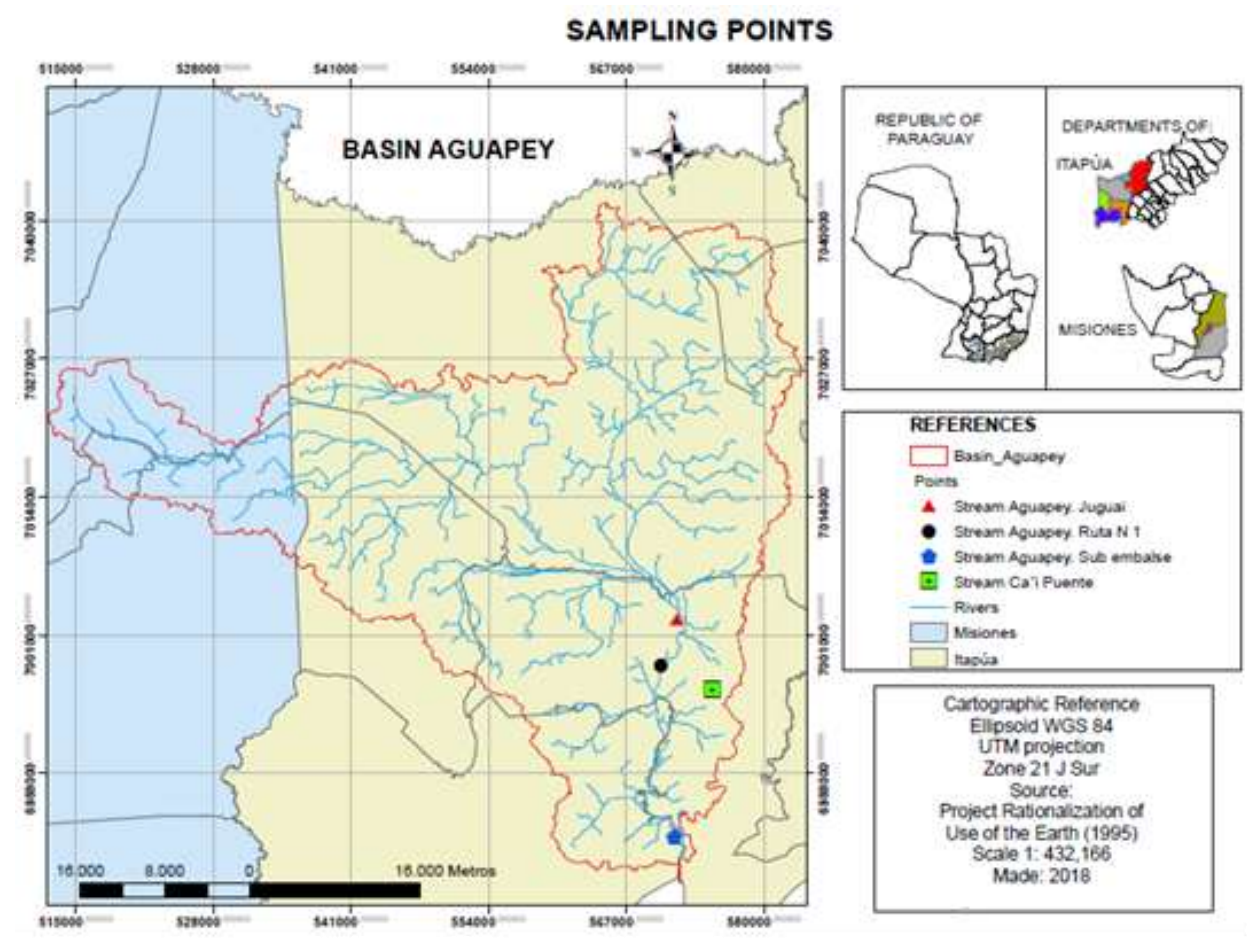

Figure $\mathbf{N}^{\mathbf{0}}$ 1:- Sampling Stations in Aguapey stream.

To collect data on the physicochemical parameters: $\mathrm{pH}$, Temperature, conductivity, SST and dissolved oxygen, a HACH Q10 multiparameter was employed; for the analysis of the COD and nitrate one liter in plastic container; and for Total Phosphorus, one liter of water was collected and refrigerated in amber glass bottle, until reaching the Laboratory, based on the "Standard Methods for the Examination of Water and Wastewater" (APHA, 2012).

To apply the ISQA, this is obtained from a formulae that combines five physicochemical parameters (Colman $\mathrm{y}$ Bellagomba, 2006): ISQA $=\mathrm{E} \cdot(\mathrm{A}+\mathrm{B}+\mathrm{C}+\mathrm{D})$, where $\mathrm{E}$ stands for water temperature $\left(\mathrm{T}\right.$ in $\left.\mathrm{C}^{\circ}\right)$, A: organic chemical demand according to the oxidability to permanganate (COD-Mn in $\mathrm{mg} / \mathrm{l}$ ), B total suspended solids (SST in $\mathrm{mg} / \mathrm{l})$, C: dissolved oxygen (O2 in $\mathrm{mg} / \mathrm{l})$ and $\mathrm{D}$ : conductivity $\left(\mathrm{CE}\right.$ in $\mu \mathrm{S} / \mathrm{cm}$ at $\left.18^{\circ} \mathrm{C}\right)$. To classify the water quality according to the numerical value of the ISQA, it was employed, considering the characteristics that the water resource must present according to the intended use (Colman y Bellagomba, 2006; Alonso, 2013): Very clear waters (85 to 100), clear (75 to 85 ), turbid (60 to 75 ), dirty (45 to 60), deteriorated (30 to 45), diluted residual (15 to 30 ), and residual ( 0 to fifteen). Later, the water quality in the stream was calculated taking into account the results acquired in the field and laboratory, considering the resolution 222/02 of SEAM (Secretaría del Ambiente Paraguay) (SEAM, 2002).

\section{Macroinvertebrates:-}

Macroinvertebrate sampling was performed according to the endorsements of Protocol sampling and analysis of benthic invertebrates (Alba-Tercedor et al., 2005). For the fordable sections for the standardization of the method, it was to sink the net bag (type D, 500 micron mesh) at the bottom of the stream in the opposite direction to the water flow, whereas ahead the operator proceeded to remove and hit the substrate dynamically with the feet, this technique was carried out in an interval of 10 seconds, in the different habitats present at the sampling point. The gathered material was emptied on white trays $(0.60 \times 0.40 \times 0.12 \mathrm{~m})$ to which water was added beforehand, then the macroinvertebrates were separated with tweezers placing them in airtight jars with ethanol at $70 \%$.

\section{Lab work:-}

It was performed observation and identification of macroinvertebrates with optical microscope and stereoscope to account for the groups discovered. Taxonomic documentations were made through key level to families: Domínguez y Fernández (2009); Lehmkuhi (1979); y Rocabado y Goitia, (2011). 
To create the graphs and calculations of physicochemical and biological variables, it was employed the statistical program PAST - Palaeontological STatistics, ver. 2.16 (Hammer et al. 2005) and Microsoft Excel 2010, such as wealth (number of families) found and estimated with Chao-1 dominance and diversity indices of Shannon-Weiner (H'), Berger-Parker y de Simpson (S) (Magurran, 2004).

\section{Results and Discussions:-}

Table 1:- Physicochemical parameters in the different seasons and sampling periods.

\begin{tabular}{|c|c|c|c|c|c|c|c|c|c|c|}
\hline \multirow{2}{*}{\multicolumn{2}{|c|}{ PERIODS }} & \multicolumn{9}{|c|}{ PARÁMETER } \\
\hline & & \multirow{2}{*}{$\begin{array}{c}\text { Temperature } \\
{ }^{\circ} \mathrm{C}\end{array}$} & \multirow{2}{*}{\begin{tabular}{|l|l}
$\begin{array}{l}\text { Electric } \\
\text { Conductivity }\end{array}$ \\
uS/cm \\
\end{tabular}} & \multirow{2}{*}{$\frac{\mathrm{SST}}{\mathrm{mg} / \mathrm{L}}$} & \multirow{2}{*}{$\begin{array}{c}\text { Dissolved } \\
\text { oxygen }\end{array}$} & \multirow{2}{*}{$\frac{\mathrm{COD}}{\mathrm{mgO}_{2} / \mathrm{L}}$} & \multirow{2}{*}{$\begin{array}{r}\mathrm{pH} \\
\mathrm{UpH} \\
\end{array}$} & \multirow{2}{*}{$\begin{array}{c}\text { Turbity } \\
\text { UTM }\end{array}$} & \multirow{2}{*}{$\begin{array}{l}\begin{array}{l}\text { Total } \\
\text { Phosphorus }\end{array} \\
\mathrm{mg} / \mathrm{L}\end{array}$} & \multirow{2}{*}{$\begin{array}{l}\text { Nitrates } \\
\mathrm{mgN} / \mathrm{L}\end{array}$} \\
\hline \multirow{5}{*}{ 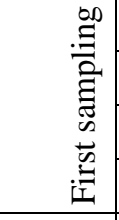 } & & & & & & & & & & \\
\hline & E1 & 19,4 & $\begin{array}{r}30 \\
\end{array}$ & 15 & 7,6 & 6,5 & 6,65 & 9,2 & 0,063 & 0,43 \\
\hline & E2 & 20,5 & 31,7 & 16 & 7,4 & 7,6 & 6,03 & 8,6 & 0,06 & 0,19 \\
\hline & E3 & 20 & 27 & 14 & 8,6 & 1,8 & 6,22 & 19,7 & 0,052 & 0,31 \\
\hline & E4 & 18 & 434 & 217 & 7,5 & 4,3 & 7,02 & 9,2 & 0,5 & 0,4 \\
\hline \multirow{4}{*}{ 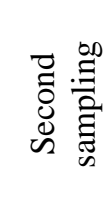 } & E1 & 27,7 & 22,2 & 14 & 3,5 & 17 & 6,6 & 6,29 & 0,05 & 0,87 \\
\hline & E2 & 27 & 21,5 & 17 & 4 & 16 & 6,53 & 6,69 & 0,05 & 0,89 \\
\hline & E3 & 25,7 & 152 & 63 & 8,16 & 15 & 6,43 & 6,3 & 0,05 & 0,4 \\
\hline & E4 & 27 & 66,3 & 20 & 2,5 & 19 & 6,3 & 7 & 0,073 & 1,2 \\
\hline \multirow{4}{*}{ 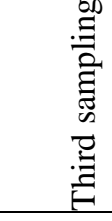 } & E1 & 27,5 & 18,5 & 26 & 6 & 11,5 & 6 & 3,2 & 0,017 & 0,01 \\
\hline & E2 & 27,6 & 19,33 & 44 & 6,7 & 10,3 & 6,1 & 3,8 & 0,024 & 0,01 \\
\hline & E3 & 27,8 & 43,2 & 48 & 9,4 & 4,6 & 7,3 & 7,1 & 0,035 & 0,01 \\
\hline & E4 & 26,5 & 375 & 244 & 4,7 & 5,3 & 7,2 & 4,8 & 0,2 & 0,01 \\
\hline \multirow{4}{*}{ 売: } & E1 & 19,8 & 16,6 & 8,3 & 6,4 & 17,95 & 6 & 4,58 & 0,021 & 0,4 \\
\hline & E2 & 20 & 15,5 & 102 & 7,2 & 6,73 & 6,19 & 6,54 & 0,05 & 0,01 \\
\hline & E3 & 20,6 & 23 & 14 & 5,2 & 4,86 & 6,95 & 14,2 & 0,044 & 1,3 \\
\hline & E4 & 21,3 & 370 & 123 & 5 & 6,73 & 7,33 & 6,54 & 0,2 & 4,3 \\
\hline
\end{tabular}

During summer period the results of the physicochemical analysis, according to Table 1 revealed a striking difference in the dissolved oxygen concentration, being lower in stations 1 and 4 , this is due to the high concentration of organic matter in the water, considering that COD level increased. According to the Generalitat de Valencia (2007), the COD allows measuring the number of organic compounds or oxidizable mineral salts found in water. The conditions improved in the following periods in most of the sampling points, but not in the E4. Citing Guerrero-Bolaño et al., (2003) and Yépez et al., (2017) the concentration of oxygen depends on the characteristics of the channel, the turbulence of the water, the chemical and biological processes as well as it influences the richness and dissemination patterns of the macroinvertebrate families. The values of $\mathrm{pH}$, Nitrate and Turbidity are within the class 2 range of water quality according to Resolution $\mathrm{N}^{\circ}$ 222/02 of the SEAM. Being the range for the $\mathrm{pH}$ from 6 to 9, the E1 was with a pH close to the lowest minimum., during summer, autumn and winter times. Correspondingly, E4 was the one with the uppermost levels of dissolved solids, which in the summer grasped $244 \mathrm{mg} / \mathrm{L}$ and a conductivity of $375 \mathrm{uS} / \mathrm{cm}$. The electrical conductivity provides an overview of the concentration of salts and ions (dissociated salts) present in water due to the urban and industrial discharges of the city (Generalitat de Valencia, 2007).

It is necessary to note that in spring and summer there was a superior agricultural activity, specifically rice crops in the upper area of the basin, where the planting and harvesting were carried out (Alonso, 2013), in alluvial plain soils, specifically Aquic Kandiudult, with low $\mathrm{pH}$ values (4.21 to $4.9 \mathrm{UpH}$ ), with a high organic matter content that directly affects water quality due to erosion effects. These soils are low in phosphorus and micronutrients, the reasons why fertilizer is usually incorporated in agriculture. The total concentration of phosphorus, remained close to the limit values established by standard maximum $0.05 \mathrm{mg} / \mathrm{L}$ for class 2 , conversely at station 4 , Cai Puente urban stream, it was significantly exceeded (Table $\mathrm{N}^{\mathrm{o}} 1$ ). Phosphorous is found in domestic sewage mainly as a 
result of its use in detergent or as part of human excretions (Correia, et al., 2013). Additional remarkable result was achieved by analyzing fecal coliforms, Station 4 with concentrations that far exceeded the upper limit of 1000 Colony Forming Units (CFU/100 ml of SEAM, for class II, since $4500 \mathrm{CFU} / \mathrm{spring}$ to $9900 \mathrm{CFU}$ in summer. Considering these data, it can be confirmed that there are leaks or fecal effluents from the urban area in the city of Coronel Bogado that reach the channel of Ca'i Puente stream, representing a threat to human health in general.

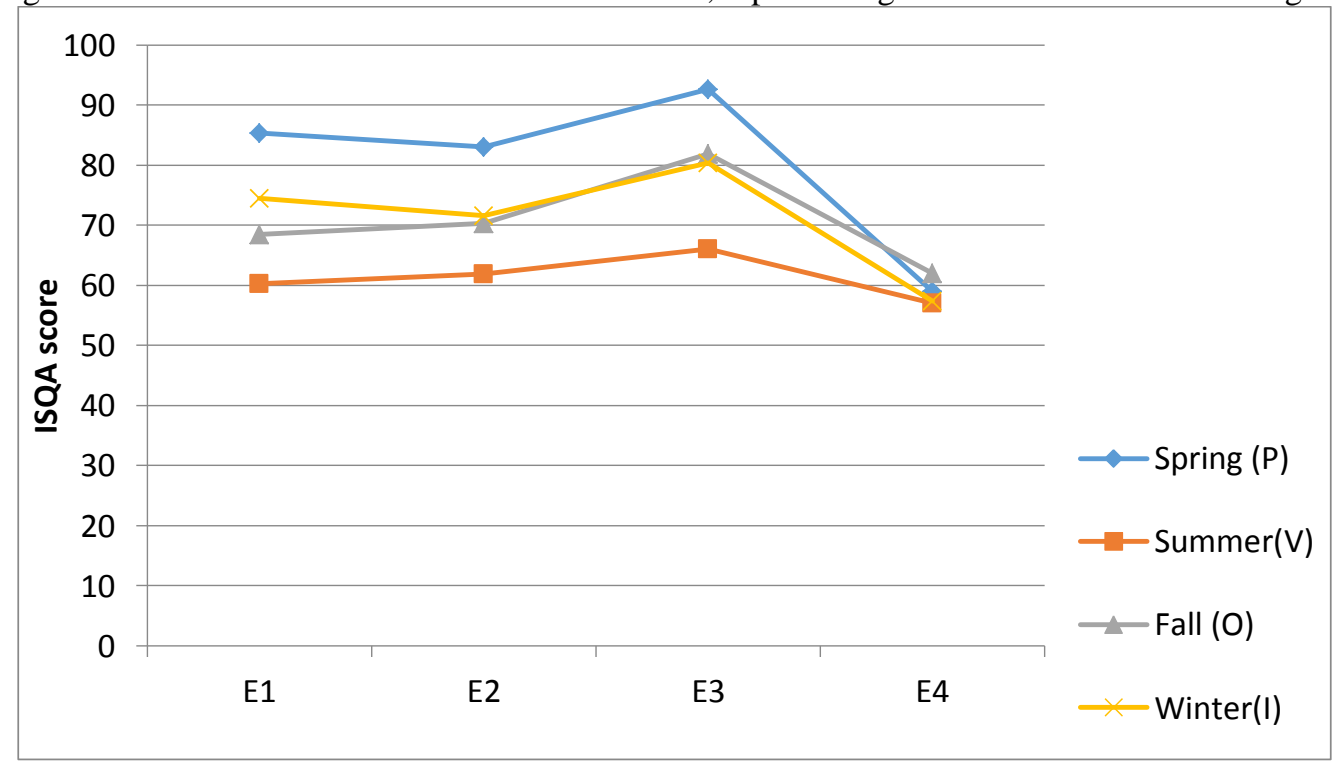

Figure 2:- Water quality according to the ISQA in the sampling stations

Figure 2 displays the different steam water qualities to the ISQA in the stations and periods in which this research was developed, as you can see the quality was changing over time, in spring, stations 1 and 2 presented clear waters and E3 "very clear waters", that is excellent, clean, with low organic content, which may have different uses; in summer, the first station went down to "dirty waters"; and E2 and E3 to "muddy waters" having substantial mineral and organic content, it is recommended activities such as fishing, but not swimming; water quality improves again in autumn and winter in the E3 to "clear waters", still being clean and easy to make drinkable and it is also available for swimming. In Station 4, of the urban stream, water quality was considered as "dirty water", with unpleasant odors and flavors, this might have been due to death fish in periods of low temperatures according to Colman and Bellagomba (2006), agreeing with the high concentration of phosphorus and low dissolved oxygen Morelli y Verdi, (2014); Yépez et al.,(2017) emphasize that physicochemical aspects of an aquatic environment, such as $\mathrm{pH}$, conductivity, dissolved oxygen and temperature, are essential aspects in the spreading of aquatic macroinvertebrates, where organisms are more sensitive.

An overall of 1691 aquatic macroinvertebrate were collected, $(\mathrm{E} 1=404, \mathrm{E} 2=364, \mathrm{E} 3=538$ and $\mathrm{E} 4=385)$, distributed in 39 different families, of 12 different orders. The family Glossiphoniidae, was the most abundant, it was followed by Chiromonidae, Baetidae, Corixidae, Naucoridae and Coenagrionida (table 2).

The real abundance (number of individuals), the estimated by Cho- 1 and wealth (number of families) in stations 1 and 2 varied during the different sampling periods. It was the station 3, which presented upper values in each period (figure 4), the highest value was observed in September, according to the Catalan Water Agency (2009), throughout the spring season the ideal environments (temperature, light and others) are created to increase the macroinvertebrate populations. E4 showed less wealth but more individuals, in summer, which is obvious in a large domain, the most abundant Glossiphoniidae, leeches freshwater predators of small organisms have been used as indicators of water quality which are typical of highly intervened areas (Figueroa et al., 2003); a different dominant Chiromonidos citing Domínguez y Fernández (2009), the significance of these organisms as bioindicators, it is due to their high tolerance to extremely polluted environments. Similar results were recorded by (Rivera et al., 2013) in the Andean urban wetland in Colombia and by Yépez et al., (2017) in Ecuador, the Tubificidae family was the most abundant in the observing stations influenced by urban discharges. The Tubificidae family is typical of eutrophized systems with abundant disintegrating organic matter found in extreme areas of contamination (Roldán, 2003). The results of the families found (taxa) and expected by Cho-1, were very alike, related results were acquired by 
Iannacone et al., (2013) in Peru, it is recommended to measure wealth of macroinvertebrate populations by Basualdo (2011) associated with other nonparametric approximations based on historical data from the neotropical region of Argentina.

Table 2:- Abundance of families found in all stations and sampling points

\begin{tabular}{|c|c|c|c|c|c|}
\hline Order & Family & Qty. & Taxa & Family & Qty. \\
\hline \multirow[t]{10}{*}{ Hemiptera } & Belostomatidae & 54 & \multirow[t]{4}{*}{ EPHENOPTERA } & Baetidae & 144 \\
\hline & Naucoridae & 127 & & Leptohyphidae & 2 \\
\hline & Nepidae & 2 & & Leptophlebiidae & 6 \\
\hline & Mesoveliidae & 1 & & Caenidae & 38 \\
\hline & Notonectidae & 12 & Entomobryomorpha & Entomobryidae & 41 \\
\hline & Veliidae & 10 & \multirow[t]{3}{*}{ DIPTERA } & Chironomidae & 178 \\
\hline & Pleidae & 6 & & Tipulidae & 10 \\
\hline & Saldidae & 2 & & Culicidae & 18 \\
\hline & Corixidae & 136 & OLIGOQUETOS & Tubificidae & 30 \\
\hline & Hydrometridae & 4 & HIRUDINEA & Glossiphoniidae & 267 \\
\hline \multirow[t]{4}{*}{ Odonata } & Aeshnidae & 4 & \multirow{5}{*}{$\begin{array}{l}\text { GASTROPODA } \\
\text { BIVALVIA }\end{array}$} & Ampullariidae & 26 \\
\hline & Libellulidae & 54 & & Planorbidae & 49 \\
\hline & Coenagrionidae & 93 & & Ancylidae & 59 \\
\hline & Gomphydae & 3 & & Sphaeriidae & 21 \\
\hline \multirow[t]{6}{*}{ Coleoptera } & Elimidae & 14 & & Physidae & 24 \\
\hline & Dytiscidae & 49 & \multirow[t]{2}{*}{ CRUSTACEA } & Aeglidae & 9 \\
\hline & Noteridae & 58 & & Hyalellidae & 31 \\
\hline & Scirtidae & 4 & \multirow[t]{2}{*}{ ARACNIDOS } & Tetragnathidae & 11 \\
\hline & Curculionidae & 2 & & Saltacidae & 26 \\
\hline & Hydrophiloidea & 66 & & & \\
\hline
\end{tabular}

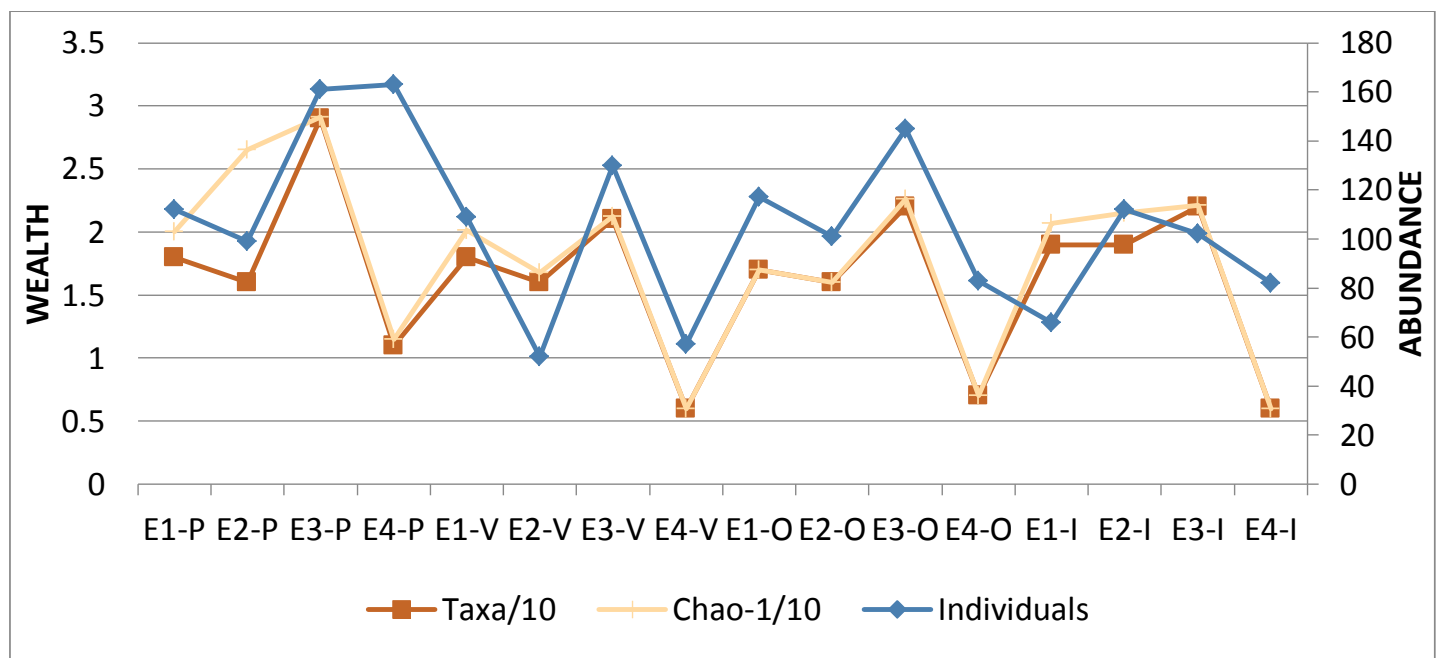

Figure 3:- Abundance (number of individuals) and wealth found (number of families) and estimated by Chao1 of the samplings. The values of family or Taxa and those of Chao-1 were divided into 10 for better demonstration in the graph. 


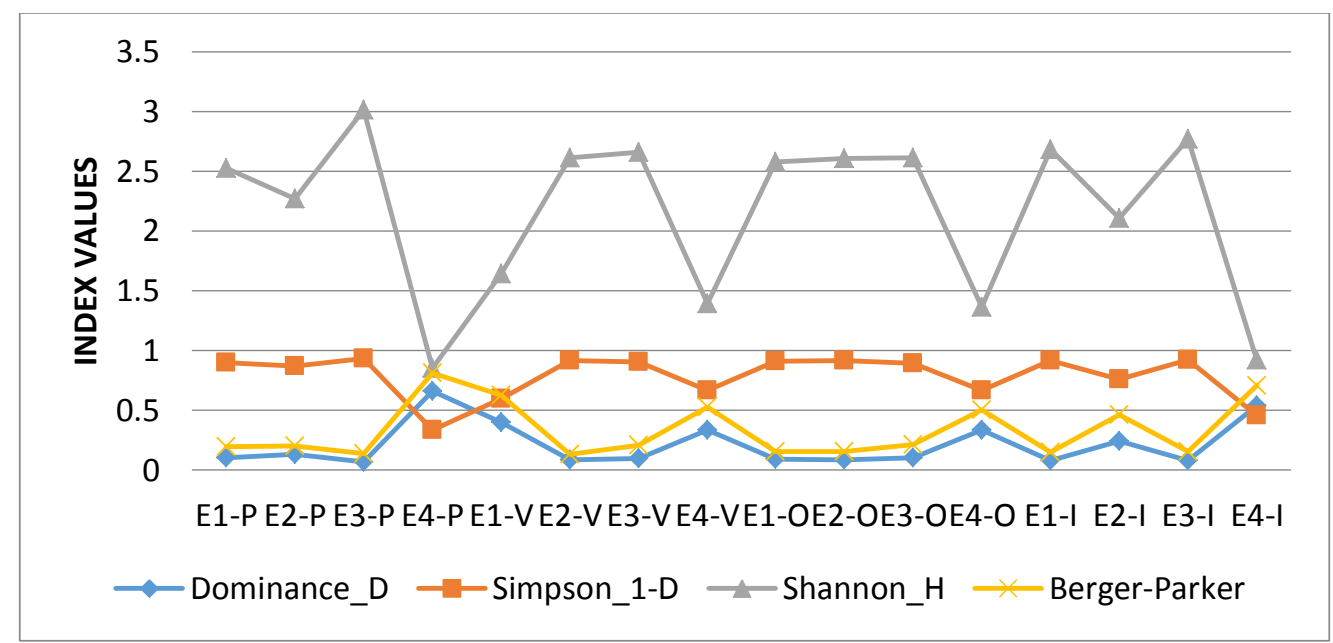

Figure 4:- Dominance outcomes, Simpson, Shannon and Berger-Parker indices.

The record diversity of Shannon was at Station 3 (values 2.5 to 3), while the E4 revealed less variety with a range of 0.8 to 1.3 (Figure 4). Equal results were stated in the Cascosa stream, Colombia, affected by discharges from urban regions, where it was documented values of diversity $\mathrm{H}$ between 0.5 -1 (Portilla, 2015, Yépez et al., 2017).

The variety of benthic macroinvertebrates in rivers and streams are influenced by specific sources of pollution and diffuse linked with urbanization, agricultural and industrial actions, simplifying its structure, affecting less wealth and diversity of families (Pavé y Marchese, 2005; Portilla, 2015; Yépez et al., 2017.

The maximum value was revealed with the application of the dominance index in Station 4 during summer time (0.6) and the lowest in E3, following the same pattern as the Berger-Parker index. Yépez et al., (2017) stated that when the macroinvertebrate community is affected declining the diversity of sensitive aquatic insects because of the abundant decaying organic substance, it rises the dominance of tolerant families with additional nutrition sources (eg. Glossiphoniidae and Chironomidae). These indices are indicators of organic pollution effects, deterioration in the morphology of the water channel and overall degradation (Gómez-Anaya, 2008).

Lastly, when the Aguapey stream water chemical indicators were analyzed, applying the ISQA and macroinvertebrates as bioindicators, they fell into the turbid category (moderately contaminated with organic matter), with stations one and two being the most affected due to farming activities and considerably improving downstream. Nonetheless, the Cai Puente stream turned out to be the most contaminated due to effluents from domestic service and industrial activities, with very high level of total phosphorus and fecal coliforms. Macroinvertebrate biodiversity and ISQA may be a helpful instrument to monitor water quality of streams and rivers.

\section{Acknowledgements:-}

This research was possible through funding provided by to the National Council of Sciences and Technologies (CONACYT) of Paraguay. 


\section{Reference:-}

1. Agencia Catalana del Agua. (2009). Calidad de agua. Recuperado el 20 de marzo de 2017, de Agencia Catalana del Agua España: http://acaweb.gencat.cat/aca/appmanager/aca/aca;jsessionid=2lz6MQjRG1Ch2Nb7klvRQz0s2vL50pxbQvdZCjT9vQ3K 8nGbnBD1!669101509!1222618062?_nfpb=true\&_pageLabel=P12000416241229447266706

2. Alba-Tercedor, J., Pardo, J., Prat, N., \& Pujante, A. (2005). Protocolos de Muestreo y Análisis para Invertebrados

3. Bentónicos. En Metodología para el establecimiento del Estado Ecológico según la Directiva Marco del Agua. (Eds. Ministerio de Medio Ambiente, Confederación Hidrográfica del Ebro y URS). Ministerio de Medio Ambiente. Madrid. España., 1-56.

4. Alonso, J. (2013). Evaluación de la calidad de las aguas del arroyo Aguapey mediante el empleo del indice simplificado de calidad de agua. Revista sobre Estudios e Investigaciones del Saber Académico, 9-13.

5. Alvarez, G. (2007). Biological indicators, a tool for assessment of the present state of a river. A preimpoundment study in the Quevedo River, Ecuador. Environmental Sciences, UNESCO-IHE, Institute for Water Education, Delft, The Netherlands., 181.

6. APHA, AWWA, \& WEF. (2012). Standard Methods for examination of water and wastewater. American Public Health Association. Washington, 1360.

7. Basualdo, C. V. (2011). Choosing the best non-parametric richness estimator for benthic macroinvertebrates databases. Revista Sociedad Emológica de Argentina, 70(1-2), 27-38.

8. Bustamante, I. d., Sanz, J., González - Hernández, F., Encabo, J., \& Mateos, J. (2002). Estudio de la calidad de las aguas superficiales en los espacios naturales del sur de las provincias de Salamanca y Ávila. Aplicaciones del índice ISQA. Geogaceta, 103-106.

9. CAN. (2015). Censo Agropecuario Nacional. Sintesis estadisticas Producción Agropecuaria $2014 / 2015$. Asunción: Ministerio de Agricultura y Ganaderia. Direccion de Censo y Estadisticas Agropecuarios.

10. Colman, G., \& Bellagomba, J. (2006). Calidad agua de cursos de Uruguay y analisis de normativas vigentes. XXX Congreso Interamericano de ingenieria y ambiente.

11. Correia, G. T., Sánchez Ortiz, I. A., Gebara, D., Dall’Aglio Sobrinho, M., \& Matsumoto, T. (2013). Remoción de fósforo de diferentes aguas residuales en reactores aeróbios de lecho fluidizado trifásico con circulación interna. Revista Facultad de Ingenieria Universidad de Antioquia(67), 172-182.

12. Domínguez, E., \& Fernández, H. (Edits.). (2009). Macroinvertebrados bentónicos sudamericanos. Sistemática y Biología. Tucumán, Argentina: Fundación Miguel Lillo.

13. Dudgeon, D., Arthington, A. H., Gessner, M. O., Kawabata, Z. I., Knowler, D. J., Lévêque, C., . . Sullivan, C. A. (2006). Freshwater biodiversity: importance, threats, status and conservation challenges. Biological Reviews, 81(2), 163-182.

14. Friedmann, A., \& Weil, B. (2010). Arroz: Negocio creciente. Informe para USAID. Asunción : Programa Paraguay Vende.

15. Garcia, X., \& Pargament, D. (2014). Rehabilitating rivers and enhancing ecosystem services in a water-scarcity context: the Yarqon River. International Journal of Water Resources Development, 73-87.

16. Generalitat de Valencia. (2007). Caracteristicas del agua. Recuperado el 22 de septiembre de 2017, de Generalitat de Valencia: http://www.cma.gva.es/areas/educacion/educacion_ambiental/educ/publicaciones/ciclo_del_agua/cicag/2/2_5_1 /main.html

17. Gómez-Anaya, J. A. (2008). Ecología de los ensamblajes de larvas de Odonatos (Insecta) y su uso potencial como indicadores de calidad ecológica de la sierra de Coalcomán, Michoacán, México. Universidad Autónoma del Estado de Hidalgo. Instituto de Ciencias Básicas e Ingenieria. Tesis en Doctorado en Recursos Bióticos.

18. Guerrero-Bolaño, F., Manjarrés-Hernandéz, A., \& Núñez-Padilla, N. (2003). The Benthonic Macroinvertebrates of Pozo Azul (Gaira River Basin, Colombia) and their Relationship with Water Quality. Acta Biológica Colombiana, 43-55.

19. Gutiérrez-Fonseca, P. E., \& Ramírez, A. (2016). Evaluación de la calidad ecológica de los ríos en Puerto Rico: principales amenazas y herramientas de evaluación. Hidrobiológica, 26(3), 433-441.

20. Hammer, O., Harper, D., \& Ryan, P. (2001). PAST: Paleontological Statistics Software Package for Education and Data Analysis. Palaeontologia Electronica, 4(1), 9.

21. Iannacone, J., Alvariño, L., Jiménez-Reyes, R., \& Argota, G. (2013). Diversidad del Plancton y Macrozoobentos com indicador alternativo de calidad de agua del río Lurín en el Distrito de Cieneguilla, Lima Perú. The Biologist (Lima), 11(1), 79-95. 
22. Lehmkuhi, D. (1979). How to know the aquatic insects. Iowa. Estados Unidos: Wn. C. Brown Company Publishers.

23. López-López, E., \& Sedeño-Díaz, J. E. (2015). Biological indicators of wáter quality: The role of fish and macroinvertebrates as indicators of water quality. (R. H. Armon, \& O. Hänninen, Edits.) Environmental indicators $\mathbb{C}$ Springer Science+Business, 650-625.

24. Magurran, A. (2004). Measuring biological diversity. London: Black Publishing, .

25. Morelli, E., \& Verdi, A. (2014). Diversidad de macroinvertebrados acuáticos en cursos de agua dulce con vegetación ribereña nativa de Uruguay. Revista Mexicana de Biodiversidad(85(4)), 1160-1170.

26. Pavé, P., \& Marchese, M. (2005). Invertebrados bentónicos como indicadores de calidad del agua en ríos urbanos (Paraná-Entre Ríos, Argentina). Ecología Austral, 15: 183-197.

27. Prat, N., Ríos, B., Acosta, R., \& Rieradevall, M. (2009). Los macroinvertebrados como indicadores de calidad de las aguas. En E. Domínguez, \& H. Fernández (Edits.), Macroinvertebrados Bentonicos sudamericanos.. (págs. 320-340). San Miguel de Tucumán: Fundación Miguel Lilio.

28. Ramírez, A., Pringle, C. M., \& Wantzen, K. M. (2008). Tropical river conservation. (D. Dudgeon, Ed.) Tropical stream ecology, 285-305.

29. Rivera, J., Pinilla, G., \& Camacho, D. (2013). Macroinvertebrados acuáticos como indicadores de calidad hidrica en áreas de descarga residuales al rio Quevedo, Ecuador. Macroinvertebrate Trophic Groups in an Andean Wetland of Colombia. Acta Biológica Colombiana, 18(2), 279-292.

30. Rocabado, G., \& Goitia, E. (2011). Guía para la Evaluación de la Calidad Acuática Mediante el Indice BMWP/Bol. La Paz: Ministerio de Medio Ambiente y Agua de Bolivia.

31. Rodriguez Badillo, L., Ríos Guayasamín, P., Espinosa Chico, M., Cedeño Loja, P., \& Jiménez Ortiz, G. (2016). Caracterización de la calidad de agua mediante macroinvertebrados bentónicos en el río Puyo, en la Amazonía Ecuatoriana. Hidrobiológica, 3(26), 497-507.

32. Roldán, G. (2003). Bioindicación de la calidad de las aguas de Colombia. Uso del método BMWP/Col. Medellin, Colombia: Universidad de Antioquia.

33. SEAM. (2002). Resolución $N^{o}$ 222. Por la cual se establece el padrón de calidad de las aguas en el territorio nacional. Asunción, Paraguay: SEAM.

34. Segnini, S. (2003). El uso de macroinvertebrados bentónicos como indicadores de la condición ecológica de cuerpos de agua corriente. ECOTROPICOS. Sociedad Venezolana de Ecología, 45-63. Recuperado el 08 de 01 de 2016, de www. ve/bitstream/123456789/25566/1/articulo1.pdf

35. Yépez, Á., Urdánigo, J. P., Morales, D. C., Guerrero, N. M., TayHing, C. C., \& Yépez, Á. R. (2017). Macroinvertebrados acuáticos como indicadores de calidad hídrica en áreas de descargas residuales al río Quevedo, Ecuador. Ciencias Ambientales/Environmental Sciences(10(1)), 27-34. 